\title{
MEMBANGUN TEACHER LEARNING CLIMATE SEBAGAI STRATEGI PENINGKATAN KUALITAS GURU
}

\author{
Anissa Lestari Kadiyono', Sekar Ayu Anjani², Serawanti Deliana ${ }^{3}$ \\ 1,2,3Fakultas Psikologi, Universitas Padjadjaran \\ ${ }^{1}$ anissa.lestari@unpad.ac.id, ${ }^{2}$ ayu.anjanisekar@gmail.com, ${ }^{3}$ seradelianaa@gmail.com
}

\begin{abstract}
Abstrak. Upaya dalam mewujudkan guru sebagai pembelajar dalam menyikapi perubahan akan tuntutan pendidikan dan kemajuan zaman membuat harus adanya upaya dari lingkungan, yaitu sekolah maupun dari dalam diri guru yang akan bersinergi untuk muwujudkan guru sebagai pembelajar. Upaya sekolah dalam mendukung pembelajaran guru di sekolah dapat dijelaskan dengan teori Teacher Learning Climate dari Marsick dan Watkins (2003). Tujuan penelitian ini adalah memberikan gambaran mengenai Teacher Learning Climate yang dapat dibangun pada guru SMP Negeri di Kota Bandung. Penelitian ini dilakukan kepada 109 guru yang aktif mengajar pada SMP Negeri di Kota Bandung. Rancangan penelitian yang digunakan adalah non-eksperimental kuantitatif. Pengambilan data dilakukan menggunakan kuesioner Teacher Learning Climate. Pengumpulan data dilakukan dengan kuesioner, kemudian diolah secara statistik. Hasil penelitian menunjukkan bahwa Teacher Learning Climate pada guru di kota Bandung dapat dibangun melalui Kolaborasi dan Kepemimpinan yang menunjang dari Sekolah. Upaya meningkatkannya melalui forum komunikasi guru dan adanya kepemimpinan yang efektif dari sekolah akan meningkatkan Teacher Learning Climate pada Sekolah Menengah Pertama Negeri di Kota Bandung. Dengan peningkatan Teacher Learning Climate, maka hal ini akan meningkatkan kualitas guru pengajar yang akan meningkatkan kualitas pendidikan secara umum.
\end{abstract}

Kata kunci: Teacher Learning Climate, Guru, Sekolah Menengah Pertama

Abstract. We needs efforts in realizing the teacher as a long-life learner in dealing with various changes will demand knowledge improvement and advancement to make them survive and will perform as well as government expected. School and their learning environment should be synergized to make a teacher as a long-life learner. School efforts in supporting teacher learning in schools can be explained by Teacher Learning Climate theory from Marsick and Watkins (2003). The purpose of this study is to provide an overview of teacher learning climate that can be built at Junior High School in Bandung. This study was conducted to 109 teachers who actively teach at Junior High School in Bandung. The research design used non-experimental quantitative. Data were collected using Teacher Learning Climate questionnaire, then processed statistically. The results showed that Teacher Learning Climate at Junior High School in Bandung city can be built from Collaboration and Leadership at School. Some efforts to improve it through teacher communication forums and the effective leadership at schools will improve Teacher Learning Climate at Junior High School in Bandung. Improving Teacher Learning Climate will fostering teacher qualitification and will make educational quality improvement.

Keywords: Teacher Learning Climate, Teacher, Junior High School 
Perubahan-perubahan pada sistem pendidikan dan kemajuan teknologi menyebabkan guru memiliki tantangan tersendiri yang harus dihadapi dalam menghadapi perkembangan jaman. Perubahan pada karakteristik siswa dan orang tua, kemajuan teknologi dan sistem informasi, perubahan kurikulum, tata cara penyelenggaraan, maupun sistem pendidikan melakukan perubahan-perubahan guna perbaikan mutu pendidikan di masa yang akan datang.

Sebagaimana yang telah tercantum pada pembukaan Undang-Undang Dasar (UUD) 1945 alinea keempat, bahwa pemerintah wajib menyediakan pendidikan untuk mencerdaskan kehidupan bangsa. Selain itu, dicantumkan pada UUD 1945 Pasal 28C Ayat (1) bahwa setiap orang berhak mengembangkan diri melalui pemenuhan kebutuhan dasarnya, berhak mendapat pendidikan dan memperoleh manfaat dari ilmu pengetahuan dan teknologi, seni dan budaya, demi meningkatkan kualitas hidupnya dan demi kesejahteraan umat manusia. Oleh karena itu, untuk menyelenggarakan suatu usaha mercerdaskan bangsa dibutuhkan suatu sistem pendidikan.

Sistem pendidikan merupakan suatu sistem yang dibentuk dengan tujuan penyelenggaraan pendidikan. Di Indonesia, sistem pendidikan telah diatur dalam Undang-Undang (UU) dengan tujuan menyamaratakan sistem yang digunakan di seluruh wilayah agar memiliki standar nasional. Menurut UU Nomor 20 Tahun 2003 yang disebut sebagai sistem pendidikan nasional adalah keseluruhan komponen yang saling terkait secara terpadu untuk mencapai tujuan pendidikan nasional, yaitu berdasar pada Pancasila dan UUD 1945, berakar pada nilai-nilai agama, kebudayaan nasional Indonesia, dan tanggap pada tuntutan perubahan zaman. Hal tersebut kemudian diatur kembali pelaksanaannya dalam Peraturan Pemerintah Republik Indonesia Nomor 13 Tahun 2015 tentang Standar Nasional Pendidikan yang membahas mengenai kriteria minimal sistem pendidikan di seluruh wilayah hukum Negara Kesatuan Republik Indonesia.

Sebagai azas pemerataan bahwa setiap orang berhak mendapatkan pendidikan, tahun 2017 juga ditetapkan bahwa sekolah negeri harus dapat menerima anak berkebutuhan khusus. Hal ini menambah fungsi dan peran guru dalam mendidik dan mengajar siswa, juga harus mampu mendampingi anak berkebutuhan khusus dalam waktu yang bersamaan. Dalam dua tahun terakhir, perubahan kurikulum pelaksanaan pendidikan yang tercatat pada tahun 2016 telah mengalami 3 kali revisi, setelah sebelumnya mengalami 11 kali perubahan sejak tahun 1947 hingga 2015 (kemdikbud.go.id).

Tantangan perubahan kurikulum, perkembangan jaman, dan era globalisasi membuat guru dituntut untuk harus selalu belajar, beradaptasi, dan mengembangkan diri terlebih dengan adanya misi tingkatkan kualitas pendidikan oleh pemerintah. Pada jenjang Sekolah Menengah Pertama (SMP), guru juga memiliki peran penting dalam menanamkan karakter. Siswa SMP yang berada pada rentang usia 12-15 tahun berada pada usia remaja yang memiliki tugas perkembangan pencarian jati diri. Hal ini membuat peran guru tidak hanya sebagai pendidik dan pengajar, namun juga berperan sebagai role model yang memberikan contoh pada siswa-siswanya. Siswa adalah generasi penerus bangsa yang juga menjadi calon pemimpin generasi berikutnya, dan memikul tanggung jawab membawa bangsa maju ke depan (Jyoti dan Sharma (2009) dalam Ayele, D. (2014)). 
Perkembangan system pendidikan, kemajuan jaman, teknologi dan informasi menyebabkan peran guru dan sekolah sebagai pusat pembelajaran mulai bergerser (Aziz Shofi, 2016). Guru dituntut untuk dapat memanfaatkan segala hal yang ada disekitarnya, termasuk teknologi untuk terlibat pada proses pengajaran pada siswa. Tentu hal ini membutuhkan dukungan dan fasilitas dari sekolah dan penyelenggara pendidikan terkait agar mempermudah belajar guru. Menurut Feiman Nemser (2001) dalam Soshani \& Eldor (2016) apabila kita menginginkan hasil pembelajaran siswa yang baik, maka kita perlu membuka kesempatan belajar yang lebih luas bagi guru.

Salah satu cara yang dapat dilakukan untuk membantu guru dalam belajar dan beradaptasi sesuai dengan perubahan-perubahan yang terjadi pada sistem pendidikan adalah dengan adanya upaya sekolah untuk mendukung pembelajaran guru atau disebut sebagai teacher learning climate. Teacher learning climate (TLC) mengacu pada berbagai norma pembelajaran dan kegiatan dimana guru berusaha untuk memperluas kemampuan mereka untuk menciptakan hasil pedagogis yang berharga dan mendorong adanya suatu pola pikir baru (Mikkelsen \& Gronhaug 1999; dalam Soshani \& Eldor, 2016). Hasil pedagogis yang dimaksud adalah seni cara mengajar guru yang menggunakan berbagai keterampilan dan kemampuannya dalam menyampaikan ilmu kepada siswa. Teacher Learning Climate bila diterjemahkan ke dalam sistem pendidikan sebagai upaya sekolah untuk mengubah belajar menjadi bagian integral dari bekerja dan memberikan kesempatan untuk belajar dan pertumbuhan berkelanjutan (Marsick, Watkins, Callahan, \& Volpe, 2009; Soshani \& Eldor, 2016). Iklim belajar guru dilakukan dalam bentuk kegiatan-kegiatan yang dapat mendorong dan membantu guru mengembangkan pola pikir dan kemampuan dirinya. Kegiatan-kegiatan tersebut termasuk menciptakan kesempatan belajar terus menerus, mempromosikan penyelidikan dan dialog, mendorong pembelajaran tim, menciptakan dan menumbuhkan visi kolektif, dan mentoring dari kepala sekolah (Eldor \& Harpaz 2016; Marsick \& Watkins, 2003; Soshani \& Eldor, 2016).

TLC mencerminkan persepsi guru tentang sejauh mana upaya sekolah mendorong pembelajaran dan memberikan kesempatan untuk pembelajaran, penyelidikan dan dialog terus menerus, pembelajaran dan timbal balik dalam tim, pemberdayaan menuju kolektif, visi, dan pembelajaran kepemimpinan (Marsick \& Watkins, 2003). Mengacu pada hal tersebut yang dimaksud dengan persepsi adalah pemaknaan informasi sensoris yang diterima secara keseluruhan menjadi model nyata yang menjadi pertimbangan dalam membuat keputusan dan melakukan tindakan (Atkinson dan Hilgard dalam Nolen-Hoeksema, 2009). Menurut Marsick dan Watkins (2003) aspek-aspek yang membentuk persepsi terhadap upaya sekolah mendukung pembelajaran guru adalah sebagai berikut:

\subsection{Create Continuous Learning Opportunities,}

Iklim belajar di desain pada sekolah agar guru dapat terus belajar dan beradaptasi pada pekerjaannya, oleh karena itu kesempatan diciptakan agar individu selalu berkembang dan memperbanyak ilmunya. Sekolah sebagai wadah pemersatu komponen-komponen didalamnya sudah seharusnya memberi kesempatan seluas-luasnya bagi guru untuk memperkaya ilmu dan mengembangkan keterampilannya. 


\subsection{Promote Inquiry and Dialogue,}

Guru mendapatkan keterampilan menalar untuk menyatakan pandangan mereka dan kapasitas mendengar serta mempertanyakan pandangan orang lain agar dapat saling berdiskusi, memberi umpan balik, dan saling mendukung dalam beberapa hal. Dalam konteks teacher learning climate, sekolah dapat menciptakan iklim pada guru untuk saling membagi ilmu pengetahuannya, mendorong usaha sesama guru lainnya untuk berkembang, serta tidak segan menanyakan hal-hal yang tidak dimengertinya.

\subsection{Encourage Collaboration and Team Learning}

Mendukung terbangunnya suatu iklim belajar dalam sekolah dapat dilihat dari seberapa sekolah mampu memfasilitasi guru untuk mengembangkan dan memperkaya ilmunya, salah satunya dengan membuat kelompok-kelompok atau forum diskusi sesama guru sekolah. Dengan dibuatnya forum tersebut guru dapat mengakses berbagai macam model berpikir, selain itu anggota dalam kelompok juga diharapkan dapat belajar dan bekerja bersama mencapai tujuan organisasi lebih mudah dengan berbagai macam pola pikir yang berbeda.

\subsection{Create Systems to Capture and Share Learning}

Iklim belajar dalam sekolah juga bertujuan untuk memajukan guru agar dapat mengikuti kemajuan teknologi, informasi, dan lain sebagainya yang berubah cepat secara global. Maka rendah-tingginya sistem teknologi yang digunakan untuk saling berbagi pembelajaran akan berintegrasi dengan pekerjaan. Dalam hal ini, sekolah yang menerapkan iklim belajar akan memberi akses yang luas pada guru di dalamnya untuk mengembangkan diri.

\subsection{Empower People Toward A Collective Vision}

Sekolah yang menerapkan suatu iklim belajar sudah seharusnya memberdayakan gurunya agar dapat bersatu mencapai tujuan bersama. Pengembangan keterampilan dan memperkaya ilmu pada setiap guru tidak hanya baik bagi individu itu sendiri tetapi juga akan memberi efek positif bagi pencapaian tujuan sekolah yang telah ditetapkan.

\subsection{Connect The Organization To Its Environment}

Dalam penerapan teacher learning climate, sekolah harus membuat koneksi dengan lingkungannya. Dengan begitu, guru sebagai sumber daya terbesar di sekolah dapat melihat efek pekerjaannya pada perusahan. Selain itu dengan meninjau dan mengenali lingkungannya serta menggunakan informasi-informasi yang ada dari sekitarnya dapat membantu mereka untuk mengadaptasikan diri pada pekerjaannya dan kemajuan dunia luar.

\subsection{Provide Strategic Leadership for Learning}

Strategic leadership merupakan suatu proses yang menggunakan taktik tertentu yang sudah dipikirkan dengan baik untuk mengomunikasikan sebuah visi bagi seuatu organisasi atau salah satu bagian dari organisasi tersebut. Sebagai sekolah yang menerapkan iklim belajar sudah seharusnya memiliki pemimpin yang senantiasa memberikan insight tersendiri bagi guru sebagai sumber daya di dalamnya untuk dapat fokus pada pencapaian visi dari sekolah tersebut, salah satunya dengan senantiasa mendukung dan mendorong mereka mempelajari teknologi dan informasi 
baru yang berkembang cepat di lingkungan. Menyediakan gaya kepemimpinan strategis yang sesuai seperti ini dapat memberi efek positif tersendiri bagi pencapaian sekolah.

Guru harus meningkatkan performa dan kemampuannya untuk menyesuaikan diri dengan perkembangan jaman dengan didukung dengan kesempatan belajar yang cukup, dukungan dari kepala sekolah dan pihak terkait, maupun dukungan dari lingkungan sekitar. Dukungan dari sekolah dan pimpinan dalam bentuk Teacher Learning Climate dapat membantu guru untuk belajar dan mengembangkan dirinya. Berdasarkan pertimbangan ini, maka perlu ditelaah lebih jauh bagaimanakah gambaran umum teacher learning climate pada guru SMPN yang dapat meningkatkan kualitas guru?"

\section{METODE}

Rancangan dari penelitian ini menggunakan pendekatan kuantitatif non-eksperimental, yaitu penelitian yang bertujuan untuk mendapatkan deskripsi atau gambaran yang akurat dari suatu situasi atau fenomena (Christensen, 2007).

Responden dalam penelitian ini adalah guru yang aktif mengajar pada periode ajar 2017/2018 di SMP Negeri Kota Bandung. Populasi guru yang terdaftar aktif mengajar di SMPN Kota Bandung periode 2017/2018 adalah sebanyak 5400 guru yang tersebar pada 54 sekolah. Sedangkan dalam penelitian ini digunakan teknik cluster random sampling, karena karakterisitk subjek bersifat homogen. Kelompok subjek dalam penelitian ini ditentukan berdasarkan jumlah SMPN yang ada di Kota Bandung, yaitu sebesar $10 \%$ dari 54 sekolah, sehingga dapat ditentukan 6 SMPN terpilih di Kota Bandung yang didapatkan dengan cara mengacak daftar 54 SMPN tersebut. Dalam penelitian ini sendiri jumlah responden yang berpartisipasi adalah 109 guru yang aktif mengajar dan tersebar pada enam SMPN Kota Bandung, yaitu SMPN 1, SMPN 2, SMPN 5, SMPN 9, SMPN 26, dan SMPN 50.

Pengambilan data dari penelitian ini dilakukan menggunakan kuesioner yang mengukur teacher learning climate yang mengacu pada alat ukur dari Marsick dan Watkins (2003) yang mengukur persepsi guru atas upaya pembelajaran guru di sekolah dan disebar pada responden dalam bentuk kuesioner yang berjumlah 18 item pernyataan dengan 6 skala alternatif jawaban dari skala 1 (sangat jarang) sampai skala 6 (sangat sering) dengan nilai reliabilitas cronbach alpha sebesar 0.890 .

\section{HASIL DAN DISKUSI}

Kapasitas dasar individu selaku pembentuk kemauan dan kemampuan guru selaku SDM dalam bertindak, berupaya, dan melekatkan diri pada sekolah membetuk perbedaan diantara individu yang satu dengan individu lainnya (Kadiyono, A. L, 2011). Dengan demikian perlu diperhatikan bahwa upaya membangun perilaku yang positif dan produktif sesuai dengan sasaran kerja dan harapan sekolah dapat dibangun dari adanya kapasitas yang memadai dari individu atau guru selaku Sumber Daya Manusia organisasi (Adha, H. F., Kadiyono, A. L., 2015). Responden pada penelitian ini berjumlah 109 guru SMP Negeri Bandung. Data demografi dilihat agar dapat dipaparkan mengenai perbedaan jenis kelamin, usia, suku bangsa, pendidikan terakhir, asal sekolah, lama 
mengajar, dan status perkawinan responden. Berdasarkan hasil olah data penelitian, maka didapatkan data pada Gambar 1.

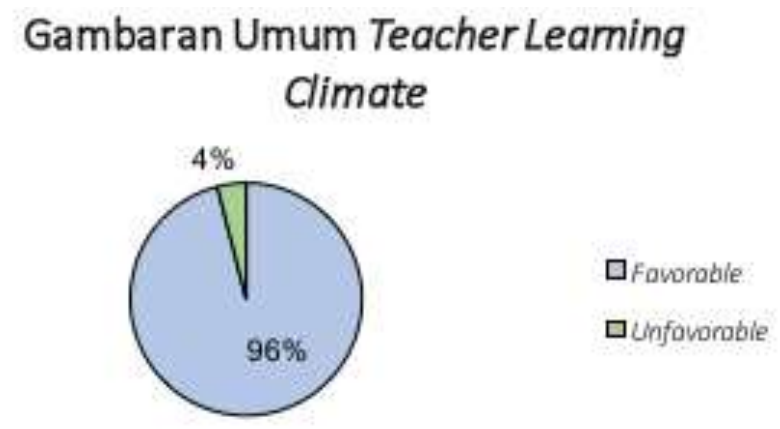

\section{Gambar 1. Gambaran Umum Teacher Learning Climate}

Berdasarkan hasil olah data penelitian, maka didapatkan sebanyak 96\% (105 responden) masuk dalam kategori iklim belajar guru favorable pada sekolah tempatnya mengajar dan 4\% (4 responden) sisanya masuk dalam kategori persepsi iklim belajar guru unfavorable. Berdasarkan hal tersebut dapat menggambarkan bahwa guru dengan kategori persepsi favorable memiliki persepsi iklim belajar guru yang baik di sekolah tempatnya mengajar, sedangkan sisanya memiliki persepsi yang cukup baik atas iklim belajar guru.

Hal ini menunjukkan data bahwa mayoritas guru SMPN Kota Bandung memberikan penilaian bahwa iklim belajar di SMPN Kota Bandung sudah baik ditandai dengan upaya-upaya yang dilakukan sekolah dalam rangka mendukung pembelajaran guru. Namun juga dapat diketahui bahwa masih terdapat sedikit responden yang menilai buruk iklim belajar guru yang ada pada sekolahnya. Selain itu, berdasarkan diagram tersebut dapat diartikan juga bahwa secara umum guru SMP Negeri Kota Bandung memiliki persepsi yang baik terhadap iklim belajar guru yang ada di sekolah. Artinya, teacher learning climate pada SMP Negeri Kota Bandung sudah baik dan sesuai dengan iklim belajar yang dibutuhkan oleh guru untuk meningkatkan kemampuan mereka agar dapat menyesuaikan pada perubahan-perubahan sistem pendidikan yang ada.

Guru-guru pada SMP Negeri di Kota Bandung merasa upaya sekolah dalam membuat lingkungan belajar dan mendukung pembelajaran sudah baik yang ditandai dengan guru-guru sudah saling terbuka dalam berdiskusi dan memberi feedback, sudah memiliki kesempatan belajar dan berkembang yang baik, sudah berkolaborasi dalam belajar, sudah saling memberdayakan untuk mencapai tujuan bersama, sudah menggunakan sistem teknologi untuk pembelajaran dan mengembangkan diri, sudah mengaitkan pekerjaan dengan lingkungan, dan sudah memiliki pemimpin yang mendukung pembelajaran guru dan fokus pada pencapaian tujuan. Namun juga dapat diketahui bahwa masih terdapat sedikit responden yang menilai buruk iklim belajar guru yang ada pada sekolahnya. Selain itu, berdasarkan diagram tersebut dapat diartikan juga bahwa secara umum guru SMP Negeri Kota Bandung memiliki persepsi yang baik terhadap iklim belajar guru yang ada di sekolah. Artinya, teacher learning climate pada SMP Negeri Kota Bandung sudah baik dan sesuai dengan iklim belajar yang dibutuhkan oleh guru untuk meningkatkan kemampuan mereka agar dapat menyesuaikan pada perubahan-perubahan sistem pendidikan yang ada.

Berdasarkan karakteristik personal yang guru miliki, didapatkan hasil pada Tabel 1. 
Tabel 1. Uji Beda Teacher Learning Climate berdasarkan Data Demografis

\begin{tabular}{lcl}
\hline \multicolumn{1}{c}{ Faktor Pembeda } & Sig. & \multicolumn{1}{c}{ Keterangan } \\
\hline Jenis Kelamin & 0.334 & Ho diterima \\
Usia & $0.035^{*}$ & Ho ditolak \\
Status Perkawinan & 0.736 & Ho diterima \\
Suku Bangsa & 0.831 & Ho diterima \\
Pendidikan Terakhir & 0.738 & Ho diterima \\
Lama Bekerja & 0.738 & Ho diterima \\
Asal SMPN & $0.000^{*}$ & Ho ditolak \\
\hline
\end{tabular}

*taraf signifikansi 0.05

Berdasarkan tabel 1. dapat dilihat bahwa jenis kelamin, suku bangsa, pendidikan terakhir, dan lama bekerja guru SMP Negeri Kota Bandung tidak memperlihatkan adanya perbedaan yang signifikan. Artinya, jenis kelamin, status perkawinan, suku bangsa, pendidikan terakhir, dan lama bekerja yang berbeda-beda pada seluruh responden tidak menyebabkan persepsi iklim belajar guru yang berbeda. Sedangkan pada asal sekolah SMP Negeri tempat bekerja guru dan usia guru memperlihatkan adanya perbedaan yang signifikan. Artinya asal SMP Negeri tempat mengajar dan usia guru yang berbeda menghasilkan perbedaan persepsi iklim belajar guru. Perbedaan persepsi akibat perbedaan usia guru tersebut dapat dilihat pada tabel 2 bahwa nilai persepsi iklim belajar guru paling besar didapatkan dari guru dengan usia young adulthood dengan skor 92.00.

Tabel 2. Skor Median Uji Beda TLC Berdasarkan Usia Guru

\begin{tabular}{cc}
\hline Usia & Skor Median \\
\hline Young Adulthood (18 - 35 Tahun) & 92.00 \\
Middle-Aged Adulthood (35 - 55 Tahun) & 88.00 \\
Older Adultood (>56 Tahun) & 85.00 \\
\hline
\end{tabular}

Perbedaan persepsi iklim belajar guru yang diakibatkan oleh adanya perbedaan usia sesuai dengan penelitian yang dilakukan oleh Mulyana (2007) bahwa perbedaan usia merupakan salah satu faktor penyebab terjadinya perbedaan persepsi, dimana individu dengan usia lebih muda biasanya memiliki sejumlah pengetahuan dan informasi yang sesuai dengan zamannya, sehingga memiliki tingkat kesesuaian persepsi yang lebih tepat dengan zaman yang lebih baru. Karakteristik personal ini menguatkan bagaimana guru selaku individu dapat berkembang sesuai dengan perkembangan jamannya (Kadiyono, A.L \& Hafiar, H., 2016).

Dalam penelitian ini, guru yang berada pada usia young adulthood (18 - 35 tahun) memiliki rata-rata skor TLC paling tinggi. Artinya hal ini sesuai dengan penelitian Mulyana (2007) bahwa guru yang berada pada usia lebih muda lebih baik persepsi TLC-nya dibanding usia middle-aged adulthood (36 - 55 tahun) dan usia older adulthood (>56 tahun) yang memiliki rata-rata skor paling kecil. Dalam penelitian ini juga diketahui bahwa baiknya persepsi TLC pada guru dengan usia young adulthood ditandai dengan pandangan mereka paling baik pada upaya sekolah memberikan mereka akses belajar tidak hanya di dalam lingkup sekolah, tapi juga di luar sekolah dan kesempatan mereka menggunakan informasi tersebut ke dalam pekerjaannya. Sehingga hal tersebut dapat membantu guru menggunakan berbagai macam cara mengajar di sekolah. 
Sedangkan perbedaan persepsi iklim pembelajaran guru SMP Negeri Kota Bandung yang disebabkan oleh perbedaan sekolah tempat mengajar guru dapat dilihat pada tabel 4.3 bahwa nilai persepsi iklim belajar guru paling besar ada pada SMP Negeri 12 Kota Bandung.

Tabel 3. Skor Median Uji Beda TLC Berdasarkan Sekolah Tempat Mengajar Guru

\begin{tabular}{cc}
\hline SMPN Tempat Bekerja & Skor Median \\
\hline SMPN 12 & 96.00 \\
SMPN 5 & 93.50 \\
SMPN 26 & 91.00 \\
SMPN 1 & 86.50 \\
SMPN 50 & 83.00 \\
SMPN 9 & 79.00 \\
\hline
\end{tabular}

Dalam penelitian ini diketahui bahwa rata-rata skor paling tinggi ada pada SMP Negeri 12 Kota Bandung, yang mana hal ini menunjukkan bahwa dari enam sekolah sampel penelitian yang diambil SMPN 12 memiliki hasil persepsi iklim pembelajaran guru paling baik. Menurut analisis peneliti dari berbagai sumber yang telah dicari bahwa visi dan misi SMP Negeri 12 Kota Bandung berfokus pada perubahan era globalisasi yang tidak hanya berfokus pada siswanya. Hal ini sesuai dengan tujuan SMP Negeri 12 Kota Bandung bahwa sekolah merupakan lembaga yang dapat merealisasikan tujuan pendidikan nasional, dengan era globalisasi yang berkembang pesat, sistem pendidikan nasional menjadi sangat penting (http://smpdualas.sch.id/). Oleh karena itu, SMP Negeri 12 Kota Bandung sangat mendorong gurunya untuk menyesuaikan diri terhadap perubahan yang berkembang pesat dengan tersedianya fasilitas dan peran yang lebih dari lingkungan sekolah. Gambaran Dimensi Teacher Learning Climate dapat dilihat pada Gambar 2.

\section{Gambaran Dimensi Teacher Learning Climate}

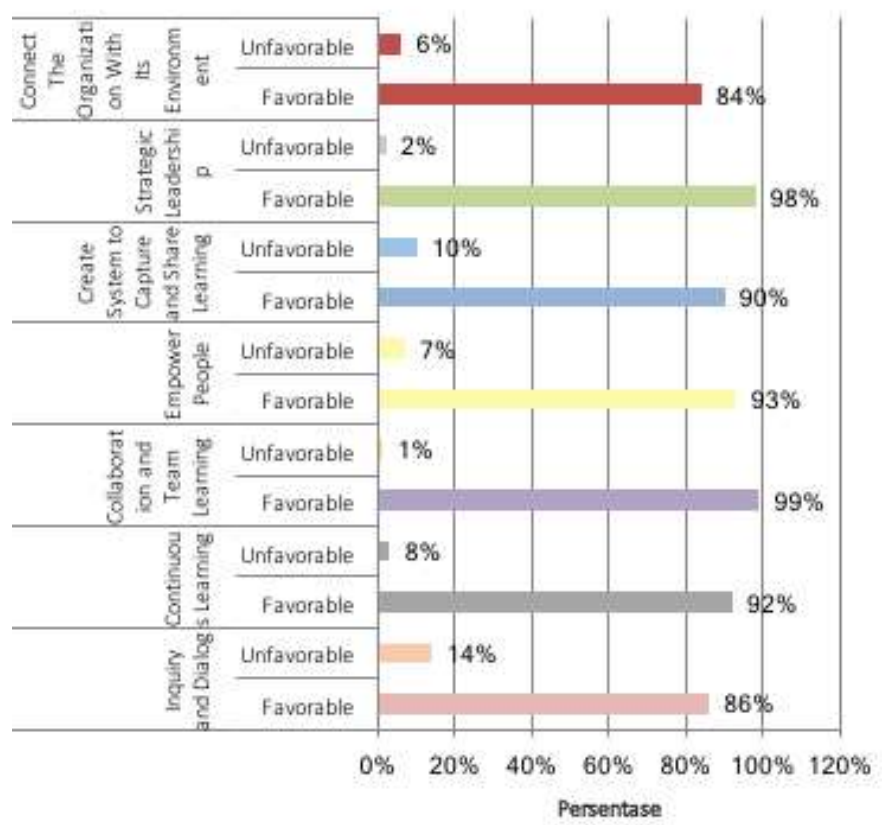

Gambar 2. Gambaran Dimensi Teacher Learning Climate 
Berdasarkan Gambar 2. dapat dijelaskan bahwa pada dimensi inquiry and dialog sebanyak 86\% (94 responden) termasuk pada kategori favorable, sedangkan sebanyak 14\% (15 responden) masuk pada kategori unfavorable. Banyaknya jumlah responden yang masuk kategori favorable pada dimensi inquiry and dialog berarti bahwa persepsi guru terhadap iklim belajar guru di sekolahnya yang mendorong mereka untuk menambah keterampilan dalam menyampaikan pendapat sangat baik. Selain itu, guru mempersepsikan dirinya sudah dapat menyampaikan pendapat, feedback, dan menggunakan keterampilan menalarnya di sekolah. Artinya, SMP Negeri Kota Bandung telah menciptakan iklim yang membantu guru meningkatkan keterampilan menyampaikan pendapat, umpan balik, dan menalar.

Kemudian pada dimensi continuous learning sebanyak 92\% (100 responden) termasuk dalam kategori favorable, sedangkan sisanya sebanyak 8\% (9 responden) masuk dalam kategori unfavorable. Hal ini berarti bahwa mayoritas responden masuk dalam kategori favorable pada dimensi continuous learning, yang menggambarkan bahwa guru-guru mempersepsikan dirinya sudah mendapatkan dukungan dan dorongan dari sekolah untuk pembelajarannya. Artinya, pada dimensi ini SMP Negeri Kota Bandung juga telah sangat baik menciptakan iklim yang mendukung guru untuk terus belajar memperluas kemampuannya agar dapat menyesuaikan diri dengan perubahan-perubahan sistem penyelenggaraan pendidikan.

Pada dimensi berikutnya, yaitu collaboration and team learning terdapat sebanyak $99 \%$ (108 responden) masuk dalam kategori favorable, sedangkan 1\% (1 responden) sisanya masuk dalam kategori unfavorable. Hal ini menandakan bahwa guru memiliki mempersepsikan dirinya telah mendapatkan wadah diskusi oleh sekolah untuk mereka dapat memperoleh berbagai macam pola pikir dan wawasan baru. Artinya, SMP Negeri Kota Bandung telah mampu menyediakan forum diskusi guru yang sesuai dengan apa yang dibutuhkan guru untuk saling berbagi ilmu dan keterampilan baru.

Setelah itu pada dimensi keempat, yaitu empower people toward a collective vision didominasi dengan 93\% (101 responden) yang masuk dalam kategori favorable, diikuti dengan $7 \%$ (8 responden) sisanya yang masuk dalam kategori unfavorable. Mayoritas jumlah responden yang masuk dalam kategori tinggi pada dimensi ini menandakan bahwa guru memiliki persepsi yang baik terhadap kemampuan sekolah mendorong seluruh anggota yang tergabung di dalamnya untuk mencapai tujuan bersama, yaitu tujuan yang telah dibuat sekolah. Selain itu, guru mempersepsikan dirinya telah diajak terlibat mencapai tujuan bersama oleh sekolah. Dalam hal ini berarti bahwa SMP-SMP Negeri Kota Bandung telah mampu mengajak anggota-anggota di dalamnya untuk bergerak mencapai tujuan bersama.

Berikutnya pada dimensi create system to capture and share learning teradpat sebanyak 90\% (98 responden) masuk dalam kategori favorable, sedangkan kategori unfavorable memiliki persentase lebih kecil yaitu sebesar 10\% (11 responden). Dimensi ini memiliki persentase paling besar pada kategori favorable. Hal ini berarti bahwa guru-guru SMP Negeri Kota Bandung memiliki persepsi yang baik pada kemampuan sekolah untuk memajukan mereka mengikuti perkembangan teknologi dan informasi secara global. Artinya guru SMP Negeri Kota Bandung mayoritas mempersepsikan bahwa sekolah telah mendorong guru untuk mengikuti perkembangan teknologi dan informasi secara global dan mengaplikasikannya langsung pada pekerjaan di sekolah. 
Kemudian pada dimensi keenam, yaitu strategic leadership persentase kategori favorable sangat mendominasi yaitu sebanyak 98\% (107 responden), yang diikuti dengan 2\% (2 responden) masuk dalam kategori unfavorable. Dominannya jumlah responden yang masuk dalam kategori favorable pada dimensi ini menggambarkan bahwa guru memiliki persepsi yang baik terhadap kemampuan pimpinan sekolahnya yang senantiasa memberikan insight kepada anggotanya untuk fokus pada tujuan bersama. Artinya, pimpinan-pimpinan SMP Negeri Kota Bandung telah mampu memberi insight pada anggota untuk berusaha mencapai tujuan sekolah di Kota Bandung.

Dimensi ketujuh atau terakhir pada teacher learning climate adalah connect the organization with its environment yang mana dimensi ini mayoritas ada pada kategori favorable sebanyak 84\% (91 responden), kemudian diikuti dengan kategori unfavorable sebesar 6\% (18 responden). Artinya, guru SMP Negeri Kota Bandung mempersepsikan sekolah telah mampu mengusahakan guru untuk membuat koneksi dengan lingkungan sekitarnya dan mendorong guru menggunakan informasi-informasi di lingkungan tersebut ke dalam pekerjaannya sehari-hari.

Hal ini menunjukkan bahwa pada SMP Negeri Kota Bandung diperlukan adanya upaya dalam memberdayakan seluruh unsur di dalamnya untuk mencapai tujuan bersama. Guru merasa bahwa upaya tersebut ditunjukkan sekolah dengan mendorong guru-guru memperluas wawasan dan keterampilan tidak hanya di dalam lingkup sekolah dalam rangka menambah inovasi dalam mencapai tujuan bersama. Dalam hal ini, kejelasan tujuan sekolah yang diselaraskan pada seluruh guru menjadi hal yang sangat penting bagi guru agar dapat memperluas keterampilan yang sesuai dengan tujuan tersebut.Tersedianya kesempatan belajar yang luas bagi guru di sekolah juga menjadi faktor yang ditunjukkan berikutnya yang dipersepsi guru SMP Negeri Kota Bandung mendukung pembelajaran mereka sebagai bentuk upaya dari sekolah. Hal tersebut ditunjukkan dengan tersedianya kesempatan belajar guru oleh sekolah dan upaya sekolah membantu guru menghadapi masalah sebagai kesempatan untuk menjadikannya pelajaran bersama, sehingga dengan hal tersebut guru dapat menemukan berbagai macam kerangka pemikiran baru.

Upaya sekolah mendorong guru untuk berhubungan dengan lingkungan luar sekolah merupakan salah satu bentuk upaya menyediakan kesempatan belajar yang luas. Misalnya sekolah dapat mendorong guru untuk berinteraksi langsung dengan siswa atau walinya di luar jam sekolah. Selain itu, kesempatan guru untuk berhubungan dengan lingkungan luar sekolah, misalnya dengan antar sekolah lain dapat membuat guru memperoleh banyak informasi terbaru yang mungkin dapat bermanfaat pada pekerjaannya sebagai guru di SMP Negeri Kota Bandung.

Keterampilan dalam menyampaikan pendapat, bertukar pikiran, menanyakan kejelasan suatu hal menjadi salah satu yang penting diupayakan sekolah untuk mendorong pembelajaran guru yang maksimal. Guru telah dapat menciptakan iklim pada guru untuk saling membagi ilmu pengetahuannya, mendorong usaha sesama guru lainnya untuk berkembang, serta tidak segan menanyakan hal-hal yang tidak dimengertinya.Upaya sekolah dalam mendorong pembelajaran guru dengan tersedianya akses guru untuk mendapatkan kesempatan belajar yang merata juga penting untuk menciptakan iklim pembelajar. 
Bila dibandingkan perbandingan rata-rata dimensinya, didapatkan data pada Tabel 4.

Tabel 4. Rata-Rata Skor Dimensi Teacher Learning Climate

\begin{tabular}{|c|c|c|}
\hline Dimensi & Rata-rata Skor & Kategori \\
\hline $\begin{array}{l}\text { Collaboration and Team } \\
\text { Learning }\end{array}$ & 5.14 & Favorable \\
\hline Strategic Leadership & 5.06 & Favorable \\
\hline Empower People & 4.79 & Favorable \\
\hline Continuous Learning & 4.75 & Favorable \\
\hline $\begin{array}{lr}\text { Connect } & \text { The } \\
\text { Organization With Its } \\
\text { Environment }\end{array}$ & 4.59 & Favorable \\
\hline Inquiry and Dialog & 4.57 & Favorable \\
\hline $\begin{array}{l}\text { Create System to Capture } \\
\text { and Share Learning }\end{array}$ & 4.47 & Favorable \\
\hline
\end{tabular}

Berdasarkan tabel 4 dapat diketahui bahwa rata-rata skor dimensi teacher learning climate paling besar ada pada dimensi collaboration and team learning, yaitu dengan rata-rata 5.14 yang artinya dimensi ini masuk dalam kategori yang favorable. Rata-rata skor yang ada pada urutan kedua adalah dimensi strategic leadership dengan rata-rata 5.06 yang masuk dalam kategori favorable. Kemudian, diikuti dengan dimensi TLC pada urutan ketiga yaitu empower people dengan angka rata-rata skor 4.79 yang masuk dalam kategori favorable. Dimensi dengan rata-rata skor pada urutan keempat adalah dimensi continuous learning dengan angka 4.75 yang artinya dimensi ini juga masuk dalam kategori favorable. Pada urutan angka rata-rata skor berikutnya adalah dimensi connect the organization with its environment dengan angka 4.59 yang juga berarti masih masuk dalam kategori favorable. Dimensi yang memiliki rata-rata skor pada urutan keenam adalah dimensi inquiry and dialog, yaitu sebesar 4.57 yang masuk dalam kategori favorable. Sedangkan pada urutan terakhir, terdapat dimensi create system to capture and share learning dengan angka sebesar 4.47. Walaupun berada pada urutan terakhir, dimensi create system to capture and share learning masih masuk dalam kategori favorable. Artinya, guru SMP Negeri Kota Bandung memiliki persepsi yang juga baik atas upaya sekolah mendorong pembelajaran mereka yang ditunjukkan dengan membuka akses belajar guru secara merata dan membantu guru mempelajari sistem teknologi terbaru yang mungkin dapat membantu penyelesaian tugas guru lebih cepat dan mudah. Secara keseluruhan, dimensi TLC masuk dalam kategori favorable yang mana keseluruhan dimensi-dimensi ini dapat menggambarkan upaya SMP Negeri Kota Bandung dalam mendukung pembelajaran guru di sekolah. Hal ini sesuai dengan penelitian sebelumnya, bahwa profesi sebagai guru menuntut untuk dapat selalu mengembangkan diri, tidak hanya didorong dari factor internal namun juga eksternal. Dorongan eksternal yang dimaksud tidak semata-mata mengenai transaksi ekonomis saja, namun lebih dari itu menemukan makna hidup dengan banyak berbagi ilmu, profesi ini sebagai bagian dari tujuan hidupnya untuk terus menemukan arti dan kesempatan dalam memberikan kebaikan pada orang lain khususnya siswa didik (Sulistiobudi, Kadiyono, Batubara, 2017).

Secara keseluruhan, artinya persepsi guru terhadap faktor-faktor pendorong iklim belajar SMP Negeri Kota Bandung semua berada pada kategori tinggi, artinya SMP Negeri Kota Bandung sudah baik menyediakan dan membuka fasilitas pembelajaran guru disertai 
dengan pemenuhan kebutuhan peran yang dibutuhkan untuk pembelajaran tersebut. Faktor yang paling utama dipandang baik oleh guru adalah tersedianya wadah diskusi guru untuk saling bertukar pikiran.

\section{SIMPULAN DAN IMPLIKASI}

Secara keseluruhan teacher learning climate pada guru SMP Negeri di Kota Bandung berada pada kategori favorable yang mengindikasikan guru secara keseluruhan merasa bahwa upaya sekolah telah mendukung pembelajarannya. Saran yang dapat diajukan berdasarkan penelitian ini adalah dengan diketahuinya bahwa iklim belajar guru yang baik dapat meningkatkan konidisi pikiran dan perasaan yang positif ketika bekerja. Maka, kesempatan pembelajaran yang telah disediakan oleh pihak sekolah dan pemerintah penting untuk diikuti sebagai wadah memperluas pengetahuan dan keterampilan yang akan membantu guru dalam menyesuaikan diri dan meningkatkan kondisi pikiran dan perasaan yang positif ketika bekerja. Selain itu, juga terdapat manfaat bagi pihak sekolah dan pemerintah, sekolah dapat memaksimalkan upaya yang mendukung pembelajaran guru di sekolah juga sebagai salah satu upaya kondisi pikiran maupun perasaan guru yang positif ketika bekerja. Sekolah dan pemerintah juga dapat menurunkan pemberian beban kerja bagi guru. Disamping itu bagi pihak pemerintah yang mengatur sistem pendidikan secara keseluruhan juga dapat memanfaatkan hasil penelitian ini sebagai acuan membentuk peraturan-peraturan baru pada sistem pendidikan yang juga mendukung pembelajaran guru sebagai upaya meningkatkan kondisi pikiran maupun perasaan positif pada guru.

\section{REFERENSI}

Adha, H. F., Kadiyono, A. L., \& Psi, M. (2015). Gambaran Mengenai Human Capital Pada Staf Bidang Pajak Pendaftaran Dan Bidang Pajak Penetapan Dinas Pelayanan Pajak Kota Bandung (Doctoral dissertation, Universitas Padjadjaran).

Brown Steven .P \& Leigh Thomas .W (1996): A new look at psychological climate and its relationship to job involvement, effort, and performance. Journal of Applied Psychology [JAP], pages 358-368

Gage, N. L., \& Berliner, D.C. (1998). Educational Psychology Edition. New York: Houghton Mifflin Company.

Gijzel, A.H.N. (2015). Time Out! The Learning Organization is here to stay. Diperoleh dari http://dspace.ou.nl/bitstream/1820/6247/1/Gijzel\%20scriptie_DEF.pdf

Goodwin, L.D \& Leech, N.L. (2003). The Meaning of Validity in The New

Standards dor Educational and Psychological Testing: Implications for Measurements Courses. American Counseling Association.

Guilford, J. P. (1956). Fundamental Statistics in Psychology and Education, $3^{\text {rd }}$ Ed. New York: McGraw-Hill. 
Jogiyanto. (2005). Analisis dan Desain Sistem Informasi. Yogyakarta: Penerbit Andi.

Kadiyono, A. L. (2011). Pengaruh Human Capital Terhadap Positive Organizational Behavior Melalui Motivasi Kerja Dan Komitmen Organisasional Sebagai Mediator (Studi Empirik Pada Pegawai Divisi Marketing Di Bumn Bidang Jasa Wilayah Jawa Barat) The Influences Of Human Capital To Positive Organizational Behavior Through Work Motivation And Organizational Commitment As Mediating Variables (The Empirical Study At Marketing Division Employees In The State Owned Enterprises Of Services Industry In West Java) (Doctoral dissertation, Universitas Padjadjaran).

Kadiyono, A. L., \& Hafiar, H. (2016). The Influence of Psychological Capital in Shaping Future Orientation at Senior High School Students in Jatinangor, Sumedang-West Java.

Kaplan, R. M., \& Sacuzzo, D. M. (2005). Psychological Testing: Principles, Application, and Issues. USA: Thomson \& Wadworth.

Mahmud. (2011). Metode Penelitian Pendidikan. Bandung: Pustaka Setia.

Marsick, V.J., Watkins, K.E. (2003). Demonstrating the Value of an Organization's Learning Culture: The Dimensions of the Learning Organization. Advances in Developing Human Resources Vol 5 No. 2

Margono, S. Margono. (2004). Metodologi Penelitian Pendidikan. Jakarta: Rineka Cipta.

Mulyana, Deddy. (2007). Ilmu Komunikasi Suatu Pengantar. Bandung: PT. Remaja Rosdakarya.

Shoshani, A., \& Eldor, L. (2016). The Informal Learning of Teachers: Learning Climate, Job Satisfaction and Teacher's and Students' Motivation And Well-Being. International Journal of Educational Research 79 (2016), Pages: 52-63.

Sugiyono. (2010). Metode Penelitian Pendidikan. Bandung: Alfabeta.

Sulistiobudi, R. A., Kadiyono, A. L., \& Batubara, M. (2017). Menemukan Kesejahteraan Psikologis Dibalik Profesi Dosen: Psychological Contract sebagai Salah Satu Prediktor Tercapainya Psychological Well Being pada Dosen. Humanitas: Jurnal Psikologi Indonesia, 14(2).

Tim Dapodikbud. (2003). Undang-Undang Republik Indonesia Nomor 20 Tahun 2003 Tentang Sistem Pendidikan Nasional. Diperoleh dari http://kelembagaan.ristekdikti.go.id/wp-content/uploads/2016/08/UU_no_20_t h_2003.pdf [13 Mei 2017].

Tim Dapodikbud. (2005). Undang-Undang Republik Indonesia Nomor 14 Tahun 2005 Tentang Guru dan Dosen. Diperoleh dari http://www.aptfi.or.id/dokumen/2005-12-30\%20UU\%20No.\%2014-2005\%20t entang\%20Guru\%20dan\%20Dosen.pdf [13 Mei 2017].

Tim Dapodikbud. (2008). Peraturan Daerah Provinsi Jawa Barat Nomor 7 Tahun 2008 Tentang Penyelenggaraan Pendidikan. 
Tim Dapodikbud. (2016). Jumlah Guru dan Siswa SMP Menurut Kecamatan di Kota Bandung, 2016).

Diperoleh

dari

https://bandungkota.bps.go.id/linkTabelStatis/view/id/100

Tim Dapodikbud. (2017a). 6 Misi Tingkatkan Kualitas Pendidikan. Diperoleh dari http://www.jabarprov.go.id/index.php/news/22180/2017/03/29/6-Misi-Tingkat kan-Kualitas-Pendidikan

Tim Dapodikbud. (2017b). Jendela Pendidikan dan Kebudayaan. Diperoleh dari http://jendela.data.kemdikbud.go.id/jendela/ [13 Mei 2017].

Tim Dapodikbud. (2017c). SMP Negeri 12 Bandung. Diperoleh dari http://smpdualas.sch.id/ [2 Oktober 2017].

Tim Dapodikbud. (2018).

https://www.kemdikbud.go.id/main/blog/2015/01/mendikbud-manusia-adalahinvestasi-terbaik-3708-3708-3708. 